\title{
State, media and pluralism: Tracing roots and consequences of media policy change in Poland
}

\author{
Beata Klimkiewicz
}

Published online: 12 April 2017

(C) The Author(s) 2017. This article is an open access publication.

\section{Introduction: What kind of media pluralism?}

Media policy rarely stands for a newsworthy topic in media coverage. Recent media policy developments in Poland, however, attract wide media coverage and the attention of governmental and non-governmental international and national organisations and bodies. This article aims at putting the debated regulatory changes into a relevant context through policy analysis. The normative concept against which the change will be tested, is media pluralism. Why? The concept of media pluralism is often viewed as an important condition for a well-functioning and democratic public sphere and media, while also incorporating political, economic and cultural value dimensions.

Yet, in the area of media policy, the concept of media pluralism 'suffers' from paradoxes. On the one hand, it has been attributed with too broad and loose interpretations (referring simply to numerous, many media). On the other hand, it has been portrayed as being too complex to be approachable by focused regulatory responses (Valcke et al. 2015; Napoli 2007). Moreover, an intense reshaping of the current digital environment led to claims that pluralism is no longer (and shouldn't be) a policy issue, due to the development of digital technological infrastructures, which solve the problems of content and distribution. While we might agree with the critics of this view of questioning technological neutrality, due to the structural conditioning of the communication environment, there is also another important dimension - normativity of media pluralism - that might be taken into account when defending the usefulness of this concept in media policies. In other words, a normative rationale for a policy action employs understanding of media pluralism as

Dr. B. Klimkiewicz $(\bowtie)$

Institute of Journalism, Media and Social Communication, ul. prof. Stanisława

Łojasiewicza 4, 30-348 Cracow, Poland

E-Mail: beatak1@hotmail.com 
a desirable and thus, not any condition. Media pluralism functions as a value-ridden term, suggesting the arrangement of media system policy that is intended.

The idea of media pluralism historically underpinned a fundamental media policy reform after the collapse of communism in Poland. The term referred to pluralism as a corrective response to previous exclusion of viewpoints, ideas, cultural representations and images from the public sphere. Thus policy ideals focused on openingup and inclusiveness of the media environment, suggesting that the media landscape needed a wide range of media outlets, and services reflecting various points of view, while recognising diverse social and cultural representations and definitions of social reality. In this sense, media pluralism seemed to be conditionally linked to the public sphere, where, as Hannah Arendt observed, there is "simultaneous presence of innumerable perspectives and aspects in which the common world presents itself" and "everything can be seen and heard by everybody" (Arendt 1958, p. 57). Such a potential inclusiveness of the public sphere is not given for granted. Jürgen Habermas sees several institutional arrangements as indispensable standards: "a separation of a (tax-based) state from a (market-based) society, communication and association rights and a regulation of the power structure of the public sphere securing the diversity of independent media, and a general access of inclusive mass audiences to the public sphere" (Habermas 2006, p. 412). Robert A. Dahl enumerates "alternative information" as one of seven essential institutional arrangements necessary for democracy (Dahl 1979, p. 223). "Alternative information" is referred to as a citizens' communicative right ("citizens have a right to seek out alternative sources of information"), empirical condition ("alternative sources of information exist") and legal obligation ("alternative sources of information are protected by law") (Dahl 1979, p. 223). In other words, "alternative sources of information" would largely, although not exclusively, correspond with the pluralistic mass media that should exist in a democratic system in order to facilitate the use of communication rights and be protected by law. Such diversity may manifest in different forms within the media environment, where scholars and policy-makers refer to 'external' and 'internal' diversity (McQuail 1992; MM-CM 1994; Voltmer 2013). 'External' pluralism stands for diversity located outside a particular media entity (and thus may be generated through various media outlets, each expressing a different point of view), while 'internal' is seen to reside inside the media organization or unit, and basically reflects differentiation of contents and services offered (including diversity of values, interests, representations and views expressed). External diversity is associated with diversity of ownership, as well as ideological, political or cultural divisions of a particular segment of the media environment, often resulting in political parallelism (Hallin and Mancini 2004). On the other hand, internal diversity is most frequently linked to the ideal purpose of the public service media (PSM), meaning that no particular groups and views are excluded, and no groups and views can expect a particularly favourable treatment either (Voltmer 2013). 


\section{A historical background}

All in all, the idea of media pluralism, as one of the basic components of a democratically functioning public sphere, served to justify a general trajectory for the media policy reform after 1989 in Poland. An overall direction of this trajectory aimed at removing the influence of the state, which manifested itself in 1990 with the elimination of institutionalised censorship and replacing it with licensing of the press and with registration by the courts. What followed then was formalized privatization, implemented by state administration according to the specific law. The policy design for privatization and the opening of the press market was guided by the idea of deregulation. The 1984 Press Law ${ }^{1}$, although amended several times up until recently, has not properly addressed questions of media pluralism, ownership, concentration and general structure of the media or press market in Poland. Thus only general competition rules regulated the mergers and acquisitions that quickly followed the initial proliferation of the press. The main direction of the broadcasting sector, which also has a general approach to media policy, was set in 1992, with an enforcement of the 1992 Broadcasting $\mathrm{Act}^{2}$, following the establishment of a broadcasting regulator - the National Broadcasting Council (KRRiT - Krajowa Rada Radiofonii i Telewizji). Article 213 of the 1997 Polish Constitution $^{3}$ set the KRRiT's role as safeguarding freedom of speech, the right to information as well as safeguarding public interest regarding radio and television broadcasting. The 1992 Broadcasting Act exposed more explicitly the need to cater for a pluralistic media landscape as seen in Article 6 (1):

"The National Council shall safeguard freedom of speech in radio and television broadcasting, protect the independence of broadcasters and the interests of the public, as well as ensure the open and pluralistic nature of radio and television broadcasting."

Yet, in the regulatory and decision-making practice, this general goal of safeguarding the pluralistic nature of radio and television broadcasting has been limited by a closed list of the regulator's power, including, among other things, the licencegranting procedures, supervising activities and programme requirements of public service media, monitoring broadcasting market and content obligations, expressing opinions that contribute to the development of media policy with no other power than the withdrawal of licences to influence market concentration and ownership changes. ${ }^{4}$

These media-policy contours concerning distinctive treatment of the press and broadcasting have endured since then, with minor or more fundamental changes introduced by subsequent governments. The role of the government has been principal

\footnotetext{
1 The 1984 Press Law Act (Ustawa Prawo Prasowe) adopted on 26 January, 1984, Official Journal 1984 No 5, item 24, as amended. .http://isap.sejm.gov.pl/DetailsServlet?id=WDU19840050024

2 The 1992 Broadcasting Act (Ustawa o Radiofonii i Telewizji) adopted on 29 December 1992, as amended, Official Journal 1993, No 7, item 34, http://isap.sejm.gov.pl/DetailsServlet? id=WDU19930070034, unofficial translation: .http://www.krrit.gov.pl/Data/Files/_public/Portals/0/ angielska/Documents/Regulations/broadcasting_act_28022013.pdf

3 The Constitution of the Republic of Poland (Konstytucja RP), adopted on 2 April 1997, Official Journal 1997, No 78, item 483, .http://www.sejm.gov.pl/prawo/konst/angielski/kon1.htm

4 Article 6 (3), 1992 Broadcasting Act.
} 
in initiating policy changes, mainly through the Ministry of Culture and National Heritage. Yet, the role of the National Broadcasting Council has also been important, in particular due to its legal mandate to issue regulations - often specifying in greater detail, the measures set in legal acts. As a result of the policy and regulatory frameworks, the structural outcome of the Polish media landscape has evolved towards the presence of private media groups (both domestic and foreign), public service media and media owned by social, educational or religious institutions (e.g., religious media, university radio networks, minority media), among which Catholic media in particular maintained a relatively strong position. It is worth to add in this context, that some Catholic broadcasters have made use of a possibility to be recognized as "social broadcasters" under the 1992 Broadcasting Act and are thus eligible for being awarded licences under special conditions (free of charge) ${ }^{5}$.

The victory of Law and Justice Party in the parliamentary election in October 2015 was marked by a historical precedent. For the first time since 1989, a single party has formed a majority government, while the President also shares the same political background. Shortly after its formation, the government proposed a set of 25 main reforms in various fields of social and economic life including family policy, public finance, national security, justice, media, under the motto of "good change" (dobra zmiana). To what extent the changes in media policy present a departure from the previous trajectory? The following parts of the article will elaborate on two aspects of media pluralism: internal - examining changing conditions for PSM and its position within the overall media system, and external - reflecting on the question of ownership, announced "repolonisation" of the media and a possible role of the state in changing structural conditions of the media environment.

\section{From state to public and from public to national media: The first step}

From the institutional perspective, public service media may be seen as a useful contribution to functional diversity within the media landscape: financed by the public with no commercial sources such as advertising, they are not forced to focus principally on the content that would best sell. Instead, they could develop services with complementary functions, such as high quality cultural programmes or more expensive news genres, which were often omitted based on economic grounds. Thus, the general condition of PSM, their strength, professional autonomy, performance quality, political independence and financial stability indicate to what extent PSM generally contribute to internal media pluralism.

PSM in Poland were created more than 25 years ago as a part of the far-reaching media reform removing the principal influence of the state. In this process, the former state media have been re-defined and legally recognized as public service media. Yet, a normative 'Western' model as a point of departure, was implemented only partially. Although legal norms granted professional autonomy to a certain extent, political control remained strong (mainly over appointments in management structures). Until the beginning of 2016, the Board of Management was appointed

\footnotetext{
5 Article 39b, 1992 Broadcasting Act.
} 
by the National Broadcasting Council. This procedure was not free from political influences. In practice, the process of board selection was, quite often, guided by political interests, due to the direct dependency relations between the National Broadcasting Council and the bodies that nominated its members - Sejm, Senate and the President. The political culture in Poland repeatedly proved that there is a big appetite for political control of both the KRRiT and PSM's Supervisory as well as Management Boards. With every change in the Parliamentary composition, the composition of the National Broadcasting Council also changed, and subsequently the composition of PSM Management Boards and Supervisory Councils (see: Jakubowicz 2004; Ociepka 2003; INDIREG 2011). Moreover, the architects of the Polish PSM model never succeeded in providing its full funding from public sources license fees. During the last 25 years, license fee revenue of the Polish Television (TVP) has oscillated between 30-17\%. In 2015, 404 mio. of PLN were collected from the licence fees, which comprised only $29 \%$ the overall cost for the realisation of public service Polish Television - 1383 mio. of PLN. In 2013, 282.4 mio. of PLN were collected from licence fees, which comprised $21 \%$ of the overall costs of production of public service - 1363 mio. of PLN. Thus, most of TVP's activities were financed from advertising, sponsoring and other commercially related sources. ${ }^{6}$ Paradoxically, problems with independent financing, have not strongly affected the position of PSM, and television in particular in audience markets. For this reason, politicians remain highly interested in maintaining some form of control over PSM and a constant 'PSM reform' has remained high in political agendas and programmes of the subsequent governments.

Not surprisingly, the Law and Justice government announced its willingness to improve conditions of PSM under the "good change" shortly after its formation in the fall 2015. The arguments of both government officials and President emphasised the necessity to improve impartiality, the national character of PSM and a greater exposure of patriotic values. On 30 December 2015, Polish Sejm enacted the so called "Small Media Act" (Mała Ustawa Medialna) amending the current 1992 Broadcasting Act. The 2015 Act was passed with great speed after the signature by the President and publication of the Act on 7 January 2016 and presented the first step towards an announced "Big Media Act" being prepared by the Ministry of Culture and National Heritage. Elżbieta Kruk, one of the Law and Justice MPs and the Chief of the Sejm Committee of Culture, backing the Act in the parliamentary debate, explained:

"The PSM ignore their mission towards the national community. They promote ideological and moral fashions that are not accepted by a societal majority. The journalists, instead of creating media exposure to Polish raison d'etre, often

\footnotetext{
6 See: KRRiT (2016) 2015 Annual Report (Sprawozdanie 2015), (http://www.krrit.gov.pl/krrit/ sprawozdania/); KRRiT (2016) Informacja o podstawowych problemach radiofonii i telewizji w 2015 roku (Information about basic issues concerning radio and television in 2015) (http://www.krrit.gov.pl/ Data/Files/_public/Portals/0/komunikaty/spr-info-krrit-2015/informacja-o-podstawowych-problemachradiofonii-i-telewizji-w-2015-roku.pdf; retrieved 17 January 2017).
} 
sympathise with unfavorable opinions regarding Poland. For the good of the national community, this should be changed as soon as possible."7

The link to "the good of the national community" and "unheard and silent majority" set a basic rhetoric line of the political argument defending a profound change of PSM in order to support and rebuild its "national" character. The nationalism argument is not new in media policies over the past two decades in Poland, albeit no previous government or parliamentary majority forced it with such enthusiasm. Against the rich discursive background, the content of the 2015 Small Media Act was fairly minimalistic: dealing solely with the PSM appointment procedure, while avoiding issues of quality of PSM performance or more comprehensively functioning of PSM or public funding - which should have been addressed in the first place. In principle, the Act contained only 4 Articles that introduced the following changes in PSM appointment and employment structure:

- Members of the Board of Management, including the President of the Board of Management and members of the Supervisory Board will by appointed by the Minister of the Treasury (Article 1)

- All terms shall be shortened and mandates shall expire for the current members of the Management and Supervisory Boards of PSM with the passing of this act $(\text { Article } 2)^{8}$

This form of appointment - although temporary (the 2015 Act expired on 30 June 2016) - created direct dependency between the government (Minister of Treasury) and PSM resulting in the extended power of political control into the PSM's employment structure. Telewizja Polska (TVP) and Polskie Radio (PR) witnessed massive layoffs of members in management and supervisory boards, but also a large number of journalists were laid off, some after 20 years of work in the public service.

\section{Reactions of European organisations}

The enforcement of the law induced strong reactions from international institutions and the European Union at the beginning of January 2016. In his letter to the Polish President Andrzej Duda, Thorbjørn Jagland, the Secretary General of the Council of Europe expressed particular concern about the new law "and the impact it may have on the integrity and independence of public service media, as a vital condition

\footnotetext{
7 TVP.info (2015) Sejm przyjął ustawę o mediach publicznych (Sejm passed the Act on Public Service Media) .http://www.tvp.info/23383140/sejm-przyjal-ustawe-o-mediach-publicznych-poslowie-pisskanduja-wolne-media

8 The 2015 Act Changing the Broadcasting Act, so called "Small Media Act" (Ustawa o zmianie ustawy o radiofonii i telewizji, tzw. "Mała Ustawa Medialna") adopted on 30 December 2015 and expired on 30 June 2016, Official Journal 2016, item 25. http://isap.sejm.gov.pl/DetailsServlet?id=WDU20160000025. See the English translation of the document: http://www.krrit.gov.pl/en/for-broadcasters-and-operators/ legal-regulations/; retrieved 12 January 2017.
} 
for genuine democracy"9. Dunja Miljatovic, OSCE Representative on Freedom of the Media warned that the controversial act gives the government "direct control over management positions in the PSB." 10 The European Commission took an unprecedented move to launch an investigation into the rule of law in Poland. Frans Timmermans, First Vice-President of the European Commission, addressing two Polish ministers (of Foreign Affairs and Justice), referred explicitly to freedom and pluralism of the media as one of the common values on which the Union is founded, adding that "Protocol 29 to the Treaties equally recognizes that the system of public broadcasting in the Member States is directly related to the democratic, social and cultural needs of each society and to the need to preserve media pluralism."11

Such strong and immediate reactions from international governmental organisations might have surprised proponents of the public media reform in Poland. All in all, PSM has experienced crises in many EU countries (Greece, Spain, Portugal), and the state administration has been involved in PSM appointment procedures in mature democracies (in 2008, the President of France took on the duty of appointing the presidents of French public broadcasters, who were previously nominated by the CSA, the French media regulator). No similar wave of criticism in scale and legal consequences has, however, been raised previously, perhaps with the exception of the enactment of Hungarian media laws in 2010. Most probably, many Polish government and state officials regarded these reactions as a disproportionate and undue attempt to interfere in the governance of PSM that were formally owned by the State. Moreover, PSM under previous managements were criticized for the lack of impartiality and inclusiveness of a broad spectrum of opinions. In one of his responses to criticism of European institutions, a spokesman for the Polish President, Marek Magierowski, supported the changes in media law claiming that under the previous government, PSM were "deeply one-party media." In his words the broadcasters had "not a penny's worth of pluralism," and "not a single EU commissioner or EU lawmaker expressed any concern over the fact." ${ }^{12}$ Certainly, a large portion of Polish journalists - and probably of society as well - shared his view. The Polish Journalists Association (SDP, Stowarzyszenie Dziennikarzy Polskich) in its statement addressed to Thorbjorn Jagland during his visit in Warsaw on April 2016 argued that public service media have not fulfilled their mission for a long time, and that SDP repeatedly called for the substantial and far-reaching reform of

\footnotetext{
9 Council of Europe (2016) Poland: Jagland raises media law human rights concerns with President Duda. (http://www.humanrightseurope.org/2016/01/poland-jagland-raises-media-law-human-rights-concernswith-president-duda/; retrieved 12 January 2017).

10 OSCE (2016) OSCE media freedom representative urges Poland's government to withdraw proposed changes to the selection of management in public service broadcasters.

(http://www.osce.org/fom/213391; retrieved 16 January 2017).

11 The letter of Frans Timmermans to the Minister of Foreign Affairs and Minister of Justice, 30 December 2015, (http://webcache.googleusercontent.com/search?q=cache:RiR3IB_n4aIJ:g8fip1kplyr33r3krz5b97d1. wpengine.netdna-cdn.com/wp-content/uploads/2016/01/Letter-Timmermans-Poland.pdf $+\& c d=3 \&$ hl=pl\& $\mathrm{ct}=\mathrm{clnk} \& \mathrm{gl}=\mathrm{pl} \& \mathrm{client}=$ firefox-b; retrieved 19 January 2017).

12 Radio Free Europe (2016) EU Executive Body to Debate Controversial New Polish Media Law (http:// www.rferl.org/a/eu-debate-new-polish-media-law/27465476.html; retrieved 17 January 2017).
} 
PSM $^{13}$. The Monitoring Centre of Free Press (CMWP) published a statement calling for the new leadership of public service media to base any personal changes on professional criteria, with regard to the fact that in past the political, family and social relations seemed to be more important in PSM employment strategies ${ }^{14}$. Yet, other journalistic communities have protested against the law changes and their consequences. SDRP (The Association of Journalists of the Republic of Poland) in its statement openly confronted the amendment of 1992 Broadcasting Act, arguing that the new law brings an end to media pluralism and objective information in $\mathrm{PSM}^{15}$. Towarzystwo Dziennikarskie (The Journalistic Association) has collected names of the "victims of the good change", including a list of journalists who have been affected by the media reform - either in forms of layoffs, employment contract changes or removals of job positions. As of January 2017, this list collected 225 such cases. ${ }^{16}$ These highly polarized evaluations of the journalistic community in Poland demonstrate cleavages rooted in different ideological perceptions of current policies - either as necessities or a turn against media freedom and pluralism. They also reveal deeper societal divides echoing the role of state (strong or weak) and dimension of national identity (promotion of national and patriotic values against cosmopolitanism).

An important aspect of the enactment of the "Small Media Act" is the change of power of the existing media regulator - National Broadcasting Council (KRRiT). In the opinion of the Polish Human Rights Defender, the Act violated constitutional guarantees of freedom of speech and media freedom by subordinating PSM directly to the government and restricting the constitutional role of the National Broadcasting Council (KRRiT) ${ }^{17}$. This opinion was partly backed on 13 December 2016 by the Constitutional Tribunal (gathered in a smaller group of five judges) in which it held certain provisions of the legislation to be unconstitutional. ${ }^{18}$

\footnotetext{
13 SDP (2016) Stanowisko SDP $w$ sprawie zmian $w$ mediach publicznych zostało przedstawione Sekretarzowi Generalnemu Rady Europy (SDP statement about changes in Public Service Media addressed to Secretary General of Council of Europe), (http://www.sdp.pl/informacje/12645, stanowisko-sdp-wsprawie-zmian-w-mediach-publicznych-zostalo-przedstawione-sekretarzowi-generalnemu-rady-europy, 1459865271; retrieved 17 January 2017).

14 SDP (2016) Apel CMWP SDP w związku ze zmianami personalnymi w mediach publicznych (CMWP and SDP appeal concerning personal change in Public Service Media), .http://www.sdp.pl/informacje/ 12281, apel-cmwp-sdp-w-zwiazku-ze-zmianami-personalnymi-w-mediach-publicznych-, 1452855142

15 SDRP (2016) Oświadczenie ZG SDRP w sprawie nowelizacji Ustawy medialnej (SDRP Board statement concerning Media Act amendment), .http://www.dziennikarzerp.p1/2016/01/oswiadczenie-zarzaduglownego-stowarzyszenia-dzniennikarzy-rp/

16 Towarzystwo Dziennikarskie (The Journalistic Association) (2017) "Dobra zmiana" w mediach ("Good change" in the media), (http://towarzystwodziennikarskie.org/; retrieved 19 January, 2017).

17 Human Rights Defender (2016) Commissioner for Human Rights Appeal to the Constitutional Tribunal on media Law, .https://www.rpo.gov.pl/en/content/commissioner-human-rights-appeal-constitutionaltribunal-media-law

18 The Constitutional Tribunal judgement No K13/16, on 13 December 2016.
} 


\section{The "Big Media Draft Law"}

The 2015 "Small Media Act" presented the first step in the process of a more profound reform concerning operation of the PSM and transforming "public service" into "national" media. On 21 April 2016, the "Big Media Law" package was submitted to the Polish Parliament. The package consisted of three draft bills, including: 2016 Draft Act on National Media, Draft Act on Audiovisual Contribution and Draft Act on Provisions introducing Act on National Media and Act on Audiovisual Contribution. ${ }^{19}$ The 2016 Draft Act on National Media postulated, among other things, the following legal changes that were neither part of the previous 1992 Broadcasting Act, nor the 2015 Small Media Act:

- renaming PSM - Polish Television (TV P - Telewizja Polska), PR - Polish Radio (Polskie Radio) and 17 regional radio stations as the "National Media" and including the Polish Press Agency (PAP - Polska Agencja Prasowa) (Article 2) in that group,

- changing the formal status of the national media from a sole-proprietor joint stock company of the State Treasury to a state legal person (Article 6),

- modifying the overall public service mission of the national media, with a recognition of priorities such as the "cultivation of national tradition, patriotic values and human values, as well as contributing to the spiritual needs of listeneres and viewers" (Article 3),

- recognition of editorial autonomy and independence of the national media (Article 5),

- modifying specific tasks towards fulfilling the public service mission, including a priority for "maintaining national community and strengthening responsibility for the common good", "enriching historical consciousness and counteracting misrepresentations of Polish history" (Article 9),

- establishment of a National Media Fund providing financing for the national media (Article 7),

- appointment of PSM top directors and boards by the Chair of the National Media Council (Articles 22, 23, 24 and 25),

- establishment of the Social Programme Councils (Articles 29-38),

- establishment of the National Media Council to take over some previous responsibilities of the National Broadcasting Council, performed at that time by the Minister of State Treasury, in particular the appointment of the executive directors of the national media and other top directors and boards, and also the supervision of the operation of the national media and operating the National Media Fund by the National Media Council (Articles 39-47).

In this form, the 2016 Draft Act on National Media, signaled the stronger connection between the state and PSM. First, this reconnection manifested itself in a symbolic and discursive level with the redefinition of "public service" as "national" media. The category of national media incorporated all media organisations

19 See: The Draft Act on National Media (Projekt Ustawy o mediach narodowych) (2016) .http://orka. sejm.gov.pl/Druki8ka.nsf/dok?OpenAgent\&8-020-177-2016 
owned formally by the state under one roof, thus adding to PSM the state-owned largest news agency in Poland - Polish Press Agency (PAP). In this way, for the first time since its transformation, PAP has been obliged to fulfill a public service mission. Given that PAP has been and continues to be the largest provider of news for other media in Poland, the way in which the public service mission is formulated in the Draft Act might have influenced editorial news performance and might have been reflectedt on all other media that use them as a source. The new public service mission proposed by the Draft Act emphasized "maintaining national community and strengthening responsibility for the common good" (Article 9.2) and "cultivation of national tradition, patriotic values and human values" (Article 3.2) among its priorities. These principles echo the idea of collective imagination of the national community once described by Benedict Anderson (1991). They proposed the view of the "national media" as spaces that can potentially contribute to revived collective imagination of the nation and strengthen the sense of community among its members through the focus on national tradition, patriotic values, reinforcing a sense of belonging to the national community and fostering responsibility for the common good of that community. The national media were also expected to "enrich historical consciousness and counteract misrepresentations of Polish history" (Article 9.3). In the opinion of the Council of Europe's experts on the three draft Acts regarding Polish public service media, particularly this last requirement should not be part of the public service mission as it seems impossible for the national media or regulator to determine what is or is not "accurate" history. ${ }^{20}$

Secondly, the stronger connection between the state and the PSM/national media was manifested in governance and the accountability of the national media. The draft law introduced a new regulatory body for the national media: National Media Council (Rada Mediów Narodowych) with a broad authority including the appointment of executive directors of the national media and other top directors and boards that supervise the operation of the national media and operating the National Media Fund (Articles 39-47). The proponents of the 2016 Draft Act in a legal justification for the introduction of the new regulatory body claimed that the National Broadcasting Council (KRRiT) combines in its mandate two contradictory functions: regulating all actors in the audiovisual market - which requires impartiality and neutrality of KRRiT towards all such players (regardless of whether they are privately or state owned) - and supervising state-owned PSM. ${ }^{21}$ Yet, the National Broadcasting Council has combined these two functions (as some other European media regulators did and do) since 1993 to fulfill its constitutionally defined role in order to safeguard

\footnotetext{
20 Council of Europe (2016) Opinion of Council of Europe Experts on the three draft Acts regarding Polish public service media, DG (2016)13, Strasbourg, 6 June 2016 (https://www.coe.int/en/ web/media-freedom/news/-/asset_publisher/RuR4jZRX8nrl/content/conclusions-of-an-expert-dialoguebetween-the-polish-government-and-the-council-of-europe?inheritRedirect=false \&redirect=https $\% 3 \mathrm{~A}$

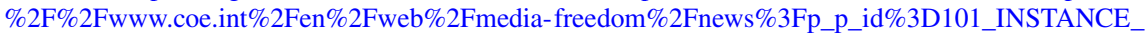
RuR4jZRX8nrl\%26p_p_lifecycle\%3D0\%26p_p_state\%3Dnormal\%26p_p_mode\%3Dview\%26p_p_col_ id\%3Dcolumn-4\%26p_p_col_count\%3D1;).

21 The Draft Act on National Media (Projekt Ustawy o mediach narodowych) (2016) .http://orka.sejm. gov.p1/Druki8ka.nsf/dok?OpenAgent\&8-020-177-2016
} 
freedom of speech, the right to information as well as to safeguard public interest regarding radio and television broadcasting. ${ }^{22}$

After numerous consultations, Poland's deputy minister of culture Krzysztof Czabański decided to postpone the 2016 Big Media Law package. The profound and farreaching changes proposed in the package would require undergoing the procedure of notification of the EU, possibly taking from a few to dozens of months.

\section{The National Media Council Act}

The June 2016 decision to postpone the Big Media Law package has certainly not marked political resignation from the project. Instead of a complex set of changes addressed in one big law package, the government decided to propose another "small" Act, focusing solely on governance of PSM, mainly due to the fact that the 2015 Small Media Act was due to expire on 30 June 2016. As a result, the new legal Act was enacted on 22 June 2016 - Act on the National Media Council. ${ }^{23}$ The Act principally deals with the new regulatory body already drafted in the "Big Media Law Draft Package" - the National Media Council (RMN - Rada Mediów Narodowych). The Act consists of 25 Articles covering following issues:

- main tasks and power of the National Media Council (Articles 1-2)

- composition and term of office of RMN (Articles 3-4),

- eligibility for membership in RMN (Article 5),

- appointment of RMN members (Article 3 and 6),

- obligations of RMN members (Article 9),

- mandate of the RMN Chairman (Article 10 and 11),

- RMN accountability procedures (Article 13),

- appointment of PSM and PAP executive directors and boards (Article 17 and 18),

- supervision of PSM and PAP by RMN (Article 17 and 18).

Formally, the 2016 Act on the National Media Council amended the 1992 Broadcasting Act $^{24}$ and 1997 Act on the Polish Press Agency ${ }^{25}$, and thus changed a number of their Articles, concerning appointment, accountability and the supervision of PSM and PAP.

With the establishment of RMN, the most controversial measure of the 2015 Small Media Act (appointment of members of PSM supervisory and management boards as well as Directors of the Polish Television and Polish Radio, by the Minister of State Treasury) was not longer in force and the power of PSM directors and

\footnotetext{
22 The Constitution of the Republic of Poland (Konstytucja RP), adopted on 2 April 1997, Official Journal 1997, No 78, item 483, http://www.sejm.gov.pl/prawo/konst/angielski/kon1.htm; Article 213.

23 Act on the National Media Council Ustawa o Radzie Mediów Narodowych, adopted on 22 June 2016, Official Journal 29 June 2016, item 929, .http://dziennikustaw.gov.pl/du/2016/929/1

241992 Broadcasting Act.

251997 Act on PAP (Ustawa o Polskiej Agencji Prasowej) adopted on 31 July 1997, Official Journal 1997, No 107 item 687, as amended .http://isap.sejm.gov.pl/KeyWordServlet?viewName=thasP\& passName=Polska\%20Agencja\%20Prasowa
} 
boards appointment was granted to RMN. The new Act provides better safeguards for balanced powers within the RMN than would be the case in a single member of government. The members (5) of the National Media Council are appointed by the Sejm (3) and President (2), who chooses the candidates from proposals of oppositional parties represented in the Sejm. Still, such a composition of the body strongly reflects the influence of political parties rather than other social or cultural groups representing e.g. educational institutions, trade unions, cultural organizations, journalistic organizations, etc. Moreover, safeguards eliminating a possible conflict of interests, seem to be rather weak. Membership in the Council excludes functions and employment in government, local self-government, Chancellery of the President of the Republic of Poland, membership in the National Broadcasting Council or holding interests or shares in media companies (Article 5.2. and 5.3.). Yet, these rules do not limit a possible membership by active politicians and the Members of Parliament. To compare these conflict-of-interest rules with those for the membership in the National Broadcasting Council (KRRiT), the RMN measures offer much weaker protection against political influence. Under the Article 214.2. of the Polish Constitution, a member of KRRiT cannot belong to a political party, or a trade union. ${ }^{26}$ This weakness in the system of governance and supervision has already manifested itself in the appointment of members to the newly established National Media Council. On 22 July 2016, the Sejm appointed three members for the National Media Council, all being Members of the Parliament - Krzysztof Czabański (who acted also as a vice-minister of culture responsible for media reform and was elected as Chairperson for the National Media Council), Elżbieta Kruk and Joanna Lichocka (all from Law and Justice Party). Two other members were proposed by the oppositional parties and appointed by the President. In October 2016, the National Media Council appointed the Executive Director of Polish Television Jacek Kurski (the same person who was previously nominated by the Minister of Treasury). The Executive Director of the Polish Radio will be appointed at the end of February 2017.

These legal and regulatory changes haven't seemed to soften the critical tone and concern about media pluralism, particularly from the European Commission. In its second recommendation, complementing the Commission Recommendation (EU) 2016/1374 regarding the rule of law in Poland, issued on 21 December 2016, the European Commission largely focusing on the crisis of the Constitutional Tribunal, refers also to new media legislation that "raises concerns relating to freedom and pluralism of the media." 27 Katrin Voltmer (2013, p. 149) pays attention to a fragile process of "tug-of-war" between state and public in new democracies:

“(...) the distinction between public service broadcasting, which serves general political purposes but keeps at arm's length from the government of the day,

\footnotetext{
26 The Constitution of the Republic of Poland.

27 European Commission (2016) Commission Recommendation of 21 December 2016 regarding the rule of law in Poland, complementary to Commission Recommendation (EU) 2016/1374, C (2016) 8950 final, (http://europa.eu/rapid/press-release_IP-16-4476_en.htm; retrieved 19 January 2017).
} 
and state television, which is dependent on and serves the interest of the government, is blurred and provides the battleground for endless power struggle between the ruling elites and broadcasters."

In the case of new media policy changes in Poland, this battleground has been deeply conditioned by a societal divide among supporters and critics of "the good change" of PSM, among proponents of a strong recognition of the national character of the national media and critics of setting frames and boundaries for collective imagination, among supporters for a closer connection of PSM and state and opponents demanding a greater distance in the use of power. And thus, internal media pluralism and the general condition of PSM has become a hostage in re-configuration of the relations between PSM and state. The question of "what kind of media pluralism?" is being replaced by the oxymoronic statement "whose media pluralism?"

\section{To regulate or not to regulate media ownership: New proposals}

Structural and media ownership regulation has been relatively limited in Poland. The basis for preventing high horizontal concentration in the press market is the general competition law. The 2007 Act on Competition and Consumer Protection does not specifically recognize the media sector, ${ }^{28}$ thus a possible procedure of intervention is one concerning the abuse of a dominant position in a relevant market. The Article 4.10 defines 'dominant position' as "a market position, which allows it to prevent effective competition in a relevant market (...); it is assumed that an undertaking holds a dominant position if its market share in the relevant market exceeds $40 \%$." In addition, the 2007 Act on Competition and Consumer Protection imposes a requirement of notification of the intention of concentration. This provision is regulated under the Article $13 .{ }^{29}$ As regards the broadcasting market, in addition to competition law, the relevant body - KRRiT - may use provisions of the 1992 Broadcasting Act for awarding, refusing or revoking licences in order to prevent a dominant position of a broadcaster in a given area. ${ }^{30}$ Current media and competition laws do not contain specific rules that could promote more competition and at the same time, prevent a high degree of cross-ownership between the different media. At the same time, the available data indicate high levels of monomedia concentration in both revenue and audience markets in Poland. In 2014, the top 4 audiovisual owners altogether achieved $93 \%$ and in 2013, 95\% of shares in the revenue market, while the top 4 radio owners $90 \%$ in 2014 and in 2013, 78\%. Likewise in the audience markets, the share of the top 4 audiovisual owners stood for $70.2 \%$ in 2015 and share of the

\footnotetext{
282007 Act on Competition and Consumer Protection (Ustawa o Ochronie Konkurencji i Konsumentów) adopted on 16 February 2007, Official Journal, 2007 No 50, item 331, as amended (available at: http://isap. sejm.gov.pl/DetailsServlet?id=WDU20070500331; retrieved 15 January 2017).

29 The 2007 Act on Competition and Consumer Protection.

301992 Broadcasting Act, Articles 36.2; 38.2.
} 
top 4 radio owners for $82.2 \% .{ }^{31}$ The share of the four leading press groups in the overall circulation of the press market reached around $70 \%$ in 2013 and $77.5 \%$ in $2014 .{ }^{32}$ Market plurality has been described as one of the areas of highest risk for media pluralism in Poland in both Media Pluralism Monitor 2015 pilot edition and the 2016 MPM report. ${ }^{33}$ The 2016 MPM country report on Poland observes:

"Key problems in this area revolve around a high level of concentration on both horizontal and cross-media markets, as well as a lack of specific rules that could, on the one hand, foster more competition and on the other hand, prevent a high degree of cross-ownership. Legally-grounded as well as selfregulatory mechanisms providing protection of journalists and editorial content against commercial and owner influence are, with some exceptions, missing in Poland. Although transparency of media ownership is guaranteed for the state agencies, the general public does not enjoy free and full access to the data about ownership and financial conditions of the media." 34

Media concentration and questions of ownership regulation can hardly be considered in Poland without the context of 'foreign' or transnational ownership. Unlike the media systems of old European democracies, various segments of the media market in Poland (with the exception of the TV sector) are dominated by transnational foreign companies. In the same vein, like other CEE countries, Poland implemented relatively permissive regulatory frameworks in the 1990s to attract rather than discourage, foreign investors. Bound by membership in the Council of Europe, EU preaccession negotiations and the significant proximity to Western Europe, the Polish media environment constituted a relatively attractive ground for foreign capital and innovation in media services (Klimkiewicz 2014). In general, Poland did not impose any limitations on foreign ownership in the sector of the print press, and some constraints in broadcasting markets have been gradually lifted in order to comply with the premises of the EU internal market. Yet, political leaders haven't dared to address intermittently foreign ownership in the political discourse - as a political problem - over the last two decades. Almost 10 years ago, Jarosław Kaczyński, the leader of the current governing party, stressed in an interview for the Channel 1 of the Polish Radio:

"A large portion of the print press in Poland belongs to German publishers. There is a need to discuss this phenomenon at the European level and limit such market developments." 35

\footnotetext{
31 KRRiT (2016) Informacja o podstawowych problemach radiofonii i telewizji w 2015 roku (Information about basic issues concerning radio and television in 2015) .http://www.krrit.gov.pl/Data/Files/_ public/Portals/0/komunikaty/spr-info-krrit-2015/informacja-o-podstawowych-problemach-radiofonii-itelewizji-w-2015-roku.pdf

32 Izba Wydawców Prasy (Chamber of Press Publishers) Lista tytułów (The List of Press Titles) (available at: http://www.iwp.pl/lista_tytulow.php?menu=2\&IWP_wydawnictwaPage=9; retrieved 15 January 2017).

33 See: (http://monitor.cmpf.eui.eu/; retrieved 19 January 2017).

34 See: (http://cmpf.eui.eu/News/All/1601MPM2016Grant.aspx; retrieved on 19 January, 2017).

35 An interview held in the first channel of the Polish public radio - PR I, in the programme Sygnały dnia (The Signals of the Day), 30.01.2007.
} 
The idea to intervene in the structural composition of the media market by the current Law and Justice government goes back to the development of general economic policy of "repolonisation", promoted as a trend aiming at re-establishment of a balance between foreign and domestic capital and strengthening the position of state-owned companies in order to make them more competitive in the EU and global markets. The concept of repolonisation has been reflected in one of PM Beata Szydlo's speeches in these words: "We need to rebuild Polish industry, regain the banking sector and the media. We need Polish production." ${ }^{36}$

One of the first moves signaling a possible regulatory change in the question of media ownership was a special meeting of the Sejm Committee on Culture organized on 30 November 2016. Jarosław Sellin, the vice minister of culture attending the meeting, claimed that discussions about the economy over the last 20 years were dominated by the belief that capital has no nationality. Yet, in the words of vice-minister Sellin, it has nationality, particularly in such a sensitive market like the media. ${ }^{37}$ In the debate, several issues were addressed, such as the possibility of introducing 20-25\% threshold for market concentration, the intention of acquiring media by state companies and the spectacular acquisition of a number of regional dailies from Mecom by Verlagsgruppe Passau (in Poland operating as Polskapresse) that led almost to a monopole structure of the regional daily newspaper market. The acquisition was formally approved in 2013 by the Office for Competition and Consumer Protection, while some MPs, during the Committee on Culture meeting, claimed that the case should be reopened and investigated again. At the beginning of 2017, a new team was formed gathering experts from the Ministry of Culture and National Heritage, Office of Competition and Consumer Protection and National Broadcasting Council. Their role will be to draft new regulations, possibly introducing media-specific rules preventing ownership concentration. The minister of culture Piotr Gliński stated that the new regulations should ensure broad media pluralism in Poland. At the same time, he assured that the rules will not tackle previous ownership changes, including mergers and takeovers, and can only address future structures. ${ }^{38}$

Media-specific anti-concentration measures are certainly missing in Poland. Yet equally important are mechanisms providing protection for journalists and editorial content against commercial and owner influence, as well as making the media ownership and financing transparent and easily available to the public. In the era of a declining role of the press, these rules and transparency measures should take into account cross-media ownership and financing from advertising.

\footnotetext{
${ }^{36}$ EU Observer (2016) Poland seeks to boost state control of economy (https://euobserver.com/beyondbrussels/132421; retrieved 20 January 2017).

37 WP money (2016) Repolonizacja mediów. PIS szykuje przepisy na zagranicznych wydawców (Repolonisation of the media. PIS prepares regulations for foreign publishers) (http://www.money.pl/ gospodarka/wiadomosci/artykul/repolonizacja-mediow-nowe-pomysly-pis, 85,0,2210389.html; retrieved 19 January 2017).

38 PAP (2016) Gliński: będą nowe regulacje dotyczące rynku mediów w Polsce, 30 December 2016 (http://www.pap.pl/aktualnosci/news, 756057, glinski-beda-nowe-regulacje-dotyczace-rynku-mediow-wpolsce.html; retrieved 20 January 2017).
} 


\section{Conclusions}

Media pluralism resembles a fragile garden. It grows and develops in an enabling environment. In harsh conditions, only the strongest species survive. The role of the state should be to foster an enabling environment and conditions for media to grow and develop. Such conditions would allow more vulnerable media, such as local, regional, special-interest, minority or community to operate side-by-side with large media groups without the threat of possible extinction or takeover. PSM should enjoy a stable position in the media system, supported by strong editorial independence and autonomy as well as sufficient long-term financing for as long as the public supports the values that PSM generate for society. Reflecting on possible consequences of the current media reform in Poland, so far focusing on PSM, the policy action seemed to start from the wrong end - tackling the issue of appointment procedure first instead of ensuring essentials such as legal guarantees of PSM editorial independence and autonomy, and a stable and long-term mode of PSM financing. Combined with the symbolic renaming of the PSM as "national media", and a proposal to rearrange the public service mission in order to promote national tradition, patriotic values and strengthen a sense of belonging to the national community, both the current and drafted legal changes signal a stronger connection between the state and PSM. Instead of strengthening the public accountability of PSM, PSM are being made accountable to the new regulatory body nominated by state institutions (the Sejm and President) and representing the political, rather than social and professional environments. Despite international criticism and strong political reactions, the Polish government position is cemented around PSM governance by the state, legitimated by a support of the significant part of the divided society and journalistic community. The state shouldn't be weak when creating an enabling media environment. It should be strong enough to ground its policy on public legitimacy that does not deepen, but attempts to bridge societal and professional divides. After all, media policy is not about establishing contours of new power relations, but balancing various interests in which the interests and needs of media users come first.

Open Access This article is distributed under the terms of the Creative Commons Attribution 4.0 International License (http://creativecommons.org/licenses/by/4.0/), which permits unrestricted use, distribution, and reproduction in any medium, provided you give appropriate credit to the original author(s) and the source, provide a link to the Creative Commons license, and indicate if changes were made.

\section{References}

Anderson, B. (1991). Imagined communities: reflections on the origin and spread of nationalism. London: Verso.

Arendt, H. (1958). The human condition. Chicago: The University of Chicago Press.

Dahl, R. (1979). Procedural democracy. In P. Laslett \& J. Fishkin (Eds.), Philosophy, politics and society: fifth series (pp. 97-133). Oxford: Basil Blackwell.

Habermas, J. (2006). Political communication in media society: does democracy still enjoy an epistemic dimension? The impact of normative theory on empirical research. Communication Theory, 16, $411-426$.

Hallin, D.C., \& Mancini, P. (2004). Comparing media systems: three models of media and politics. Cambridge: Cambridge University Press. 
INDIREG Final Report (2011). Indicators for independence and efficient functioning of audiovisual media services regulatory bodies for the purpose of enforcing the rules in the AVMS Directive (SMART 2009/0001). http://ec.europa.eu/avpolicy/docs/library/studies/regulators/final_report.pdf. Accessed 10 January, 2017.

Jakubowicz, K. (2004). Ideas in our heads: introduction of PSB as part of media system change in Central and Eastern Europe. European Journal of Communication, 19, 53-74.

Klimkiewicz, B. (2014). A Polyvalent media policy in the enlarged European Union. Kraków: The Jagiellonian University Press.

McQuail, D. (1992). Media performance. Mass communication and the public interest. London: SAGE.

MM-CM, Council of Europe's Committee of Experts on Media Concentrations and Pluralism (1994). The activity report of the committee of experts on media concentrations and pluralism. submitted to the 4th European Ministerial Conference on Mass Media Policy, Prague, 7.-8. Dec 1994.

Napoli, P. M. (Ed.). (2007). Media diversity and localism: meaning and metrics. Mahwah: LEA Publishers.

Ociepka, B. (2003). Dla kogo telewizja? Model publiczny w postkomunistycznej Europie Środkowej. (Whose television? The public service model in post-communist Central Europe). Wrocław: Wydawnictwo Uniwersytetu Wrocławskiego.

Valcke, P., Pickard, R., \& Sükösd, M. (2015). Media pluralism and diversity: concepts, risks and global trends. Basingstoke: Palgrave Macmillan.

Voltmer, K. (2013). The Media in Transitional Democracies. Cambridge: Polity Press.

Dr. Beata Klimkiewicz is Associate Professor at the Institute of Journalism, Media and Social Communication at Jagiellonian University, Cracow, Poland 